\title{
Analysis of Agricultural Products Logistics in Hunan Province and Green Development Countermeasures
}

\author{
Dan $\operatorname{Tan}^{1} \&$ Yajiao Tang ${ }^{1}$ \\ ${ }^{1}$ College of Economics, Central South University of Forestry and Technology, Changsha, China \\ Correspondence: Dan Tan, College of Economics, Central South University of Forestry and Technology, No.498 \\ South Shaoshan Road, Tianxin District, Changsha 410004, China. Tel: 86-137-8741-8695. E-mail: \\ tan_dan@126.com
}

$\begin{array}{lc}\text { Received: March 4, } 2015 & \text { Accepted: March 29, } 2015 \quad \text { Online Published: May 31, } 2015 \\ \text { doi:10.5539/jms.v5n2p146 } & \text { URL: http://dx.doi.org/10.5539/jms.v5n2p146 }\end{array}$

This work is supported by the funds project under the Education Department of Hunan Province for outstanding young people under Grant No.13B152 and the general project under the Education Department of Hunan Province under Grant No. 13 C1165.

\begin{abstract}
Hunan is an agricultural province with abundant output of agricultural products and frequent agricultural products logistics activities. However, the level of its agricultural products logistics is still low and the "negative external effect" of high energy consumption, big loss, environment pollution and waste of resources still exists in the logistics process. The agricultural products logistics of Hunan Province needs to take a green development way with attributes of efficient energy-saving and low wastage. Based on factor analysis and cluster analysis, this paper analyzed agricultural products logistics conditions of 14 cities of Hunan province, from the perspective of supply, demand and energy consumption. Relevant development countermeasures were given according to the results of empirical analysis.
\end{abstract}

Keywords: agricultural products logistics, green development, factor analysis, cluster analysis, Hunan Province

\section{Introduction}

Hunan Province is located in the south of the Yangtze River, which belongs to the middle reaches of the Yangtze River area, since the ancient times to enjoy the reputation of "a land flowing with milk and honey". The region's GDP reached 2,215.42 billion Yuan in 2012, with the growth of $11.3 \%$, and ranked $10^{\text {th }}$ in the whole country. At the end of 2011, the provincial highway traffic total mileage reached 232,200 kilometers, and the road network density is $106.36 \mathrm{~km} /$ hundred square kilometers. The road has reached $100 \%$ of the villages and towns in the whole province. Its shipping conditions are very superior. The existing navigable rivers in this province are 373 , and the provincial traffic mileage reaches 11,900 kilometers, accounting for about $1 / 10$ of the inland river navigable mileage of the country, ranking the third in the nation. Hunan is a major agricultural province, with abundant agricultural products. The total output value of agricultural products in 2012 is 490.41 billion Yuan, with the increase of $3 \%$ over the previous year. With its special geographic position, Hunan Province has huge inflow and outflow of agricultural products every year. Although the agricultural products logistics activities in Hunan Province are frequent, yet the level of logistics activities is still relatively low. The circulation channel of agricultural products is complex and unstable. The normative systematic management and control of the procurement, transportation, processing, warehousing, packaging, and distribution of agricultural products does not establish. The safety, health and environment protection have not been paid enough attention in the process of agricultural products circulation. The "negative external effect" of high energy consumption, big loss, exhaust emission, noise pollution and waste of resources does exist. The agricultural products logistics of Hunan Province needs to take a green development way with attributes of efficient energy-saving and low wastage. Therefore, this paper makes the evaluation on the situation of the agricultural products logistics of 14 cities in Hunan Province by using the factor analysis and cluster analysis method, and provides the development measures according to the empirical results. 


\section{Literature Review}

There are some scholars have studied the agricultural products logistics in Hunan Province. HUANG Fuhua and ZHOU Min (2008) analyzed the situation and problem of agricultural products logistics in Hunan Province from the perspective of joint logistics and proposed the countermeasures of developing joint logistics of agricultural products. PANG Yan and WANG Zhongwei (2009) put forward the thoughts of constructing modern logistics system of agricultural products of Hunan Province. ZHOU Xiaomei and LI Qianlan (2010) came up with the recommendation of the industrialized operation of agricultural products logistics in Hunan Province, from the perspective of logistics circle construction, information sharing, logistics channel establishment and demonstrative agricultural products wholesale market construction. LI Ming (2011) conducted the data statistics of the operation situation of agricultural products logistics of Hunan Province, and raised the development suggestions from the aspects of awareness, legal system, standard, principal part, environment, human resource and technology. LIU Changjun (2011) put forward the security mechanism of the development of agricultural products logistics in Hunan Province. These researches have established the good foundation of the development of agricultural products logistics of Hunan Province. However, there is a lack of research on evaluating the agricultural products logistics in Hunan.

\section{Methodology}

The factor analysis method is developed by Karl Pearson and Charles Spearmen at the beginning of $20^{\text {th }}$ century, based on the statistics and analysis of the intelligence test. It is a mathematical procedure used to reduce a large amount of data into a structure that can be more easily studied. It takes the minimal loss of information as the premise, starting from the internal dependence of the correlation matrix, integrating many variables into a few indicators, which called factor. In other words, it summarizes information contained in a large number of variables and condenses it into a smaller number of factors containing variables that are interrelated.

Cluster Analysis was originated in anthropology by Driver and Kroeber in 1932 and introduced to psychology by Zubin in 1938 and Robert Tryon in 1939 and famously used by Cattell beginning in 1943 for trait theory classification in personality psychology. It is a multivariate analysis technique that seeks to organize information about variables so that relatively homogeneous groups, or "clusters", can be formed.

\section{Study process and results}

\subsection{The Selection of Sample Indicators and Data}

The factor analysis requires that the number of samples should be more than the number of indicators and the KMO test should also be passed. In general, the value of KMO should be higher than 0.6, then the factor analysis can be conducted. At present, the system of statistical methods for regional agricultural products logistics level has not yet formed in China. Based on the principle of relevance, according to the influencing factors of regional agricultural products logistics indicators, the evaluation indicators of factor analysis on agricultural products logistics in Hunan province were preselected through reading books or statistical yearbook, consulting the relevant departments, web search and other means. 36 indicators were initially identified to represent the level of agricultural products logistics in Hunan province. The data statistics of some indicators were found incomplete or could not be acquired during the process of investigation. Since the research object is the 14 cities in Hunan Province, the number of sample is 14 , which means the number of factors must be restricted within 13 indicators. Therefore, the 36 indicators have been screened and those indicators which are similar to each other or reflect the same aspect of agricultural products logistics were deleted. 12 indicators which can better reflect the level of regional agricultural products logistics and energy consumption have been chosen to construct the evaluation system of agricultural products logistics in Hunan Province. These indicators are: $\mathrm{X}_{1}$ (Regional GDP), $\mathrm{X}_{2}$ (Population), $\mathrm{X}_{3}$ (Gross output value of farming, forestry, animal husbandry and fishery), $\mathrm{X}_{4}$ (Total output of agricultural products), $\mathrm{X}_{5}$ (Employees in traffic, transport, storage and post), $\mathrm{X}_{6}($ Number of civil vehicles owned), $\mathrm{X}_{7}$ (Total length of highways), $\mathrm{X}_{8}$ (Freight traffic), $\mathrm{X}_{9}$ (Revenue from postal and telecommunication Service), $\mathrm{X}_{10}\left(\right.$ Investment in transport, storage and post), $\mathrm{X}_{11}$ (Number of internet users), $\mathrm{X}_{12}$ (Opposite number of energy consumption of unit GDP).Taking the opposite number of energy consumption of unit GDP as one of the indicators is in order to reflect the energy consumption situation of agricultural products logistics activities. The less energy the agricultural products logistics activities consume, the higher the opposite number of energy consumption is, which shows that the green degree of agricultural products logistics activities is higher.

\subsection{The Raw Data of Indicators}

In the evaluation indicators system, the raw data of indicators of the 14 cities is shown as table 1 . The data are obtained from the "Hunan statistical yearbook 2012" and the yearbook 2012 of each city and has been processed. 
The agricultural products mentioned in $\mathrm{X}_{4}$ (Total output of agricultural products) contain grain, oil, fruit, meat, dairy, aquatic products, vegetables and cotton.

Table 1. The raw data of factor analysis of agricultural products logistics in Hunan Province

\begin{tabular}{|c|c|c|c|c|c|c|c|c|c|c|c|c|}
\hline $\begin{array}{l}\text { Name of } \\
\text { the city }\end{array}$ & $\begin{array}{l}X_{1} \\
(100,000, \\
000 \text { yuan })\end{array}$ & $\begin{array}{l}X_{2} \\
(10,000 \\
\text { person })\end{array}$ & $\begin{array}{l}X_{3} \\
(10,000 \\
\text { yuan }) \\
\end{array}$ & $\begin{array}{l}X_{4} \\
(10,000 \\
\text { ton })\end{array}$ & $\begin{array}{l}X_{5} \\
(10,000 \\
\text { person })\end{array}$ & $\begin{array}{l}X_{6} \\
\text { (unit) }\end{array}$ & $\begin{array}{l}\mathrm{X}_{7} \\
(\mathrm{~km})\end{array}$ & $\begin{array}{l}X_{8} \\
(10,000 \\
\text { ton) }\end{array}$ & $\begin{array}{l}X_{9} \\
(100,000, \\
000 \text { yuan })\end{array}$ & $\begin{array}{l}X_{10} \\
(10,000 \\
\text { yuan })\end{array}$ & $\begin{array}{l}X_{11} \\
(10,000 \\
\text { subscribers })\end{array}$ & $\begin{array}{l}\mathrm{X}_{12} \\
\text { (ton SCE/ } \\
10,000 \text { Yuan }\end{array}$ \\
\hline Changsha & 5619.33 & 709.07 & 3877162.00 & 836.19 & 1.66 & 1193649.00 & 15438.21 & 25651.00 & 106.31 & 2125515.00 & 111.54 & -0.640 \\
\hline Zhuzhou & 1564.27 & 388.08 & 1917342.00 & 462.02 & 0.32 & 526021.00 & 13531.15 & 14760.00 & 29.91 & 143557.00 & 41.97 & -0.964 \\
\hline Xiangtan & 1124.14 & 276.45 & 1718823.00 & 356.50 & 0.50 & 400108.00 & 7784.08 & 8220.69 & 22.45 & 206275.00 & 24.10 & -1.301 \\
\hline Hengyang & 1734.30 & 716.60 & 4746623.00 & 840.89 & 0.36 & 616240.00 & 20569.04 & 17680.00 & 34.55 & 271870.00 & 44.34 & -0.887 \\
\hline Shaoyang & 907.23 & 710.72 & 3185620.00 & 664.75 & 1.36 & 547924.00 & 21609.36 & 15610.80 & 29.73 & 506529.00 & 34.47 & -0.935 \\
\hline Yueyang & 1899.49 & 548.53 & 3805034.00 & 748.04 & 1.01 & 432391.00 & 20076.05 & 16542.49 & 32.36 & 120771.00 & 40.58 & -1.006 \\
\hline Changde & 1811.19 & 573.26 & 4692046.00 & 817.81 & 0.36 & 748829.00 & 22160.17 & 10401.00 & 34.14 & 337058.00 & 41.13 & -0.727 \\
\hline Zhangjiajie & 298.04 & 149.01 & 615189.20 & 148.55 & 0.34 & 171804.00 & 8739.67 & 1755.00 & 10.76 & 79814.00 & 13.42 & -0.700 \\
\hline Yiyang & 883.63 & 431.44 & 2902927.00 & 612.33 & 0.38 & 464119.00 & 15819.18 & 9026.00 & 23.91 & 181091.00 & 22.95 & -0.828 \\
\hline Chenzhou & 1346.38 & 460.52 & 2480990.00 & 539.23 & 0.40 & 550862.00 & 16991.13 & 19436.00 & 24.98 & 612686.00 & 29.85 & -1.017 \\
\hline Yongzhou & 945.39 & 521.25 & 4060190.00 & 954.03 & 0.46 & 587063.00 & 22601.58 & 8322.00 & 22.95 & 57400.00 & 25.36 & -0.943 \\
\hline Huaihua & 845.63 & 475.10 & 2157271.00 & 452.67 & 0.96 & 487785.00 & 19999.54 & 3880.08 & 23.91 & 183894.00 & 27.94 & -0.884 \\
\hline Loudi & 847.26 & 379.32 & 2139091.00 & 309.12 & 0.49 & 512531.00 & 14611.52 & 14476.34 & 23.89 & 337794.00 & 26.85 & -1.821 \\
\hline West & 361.37 & 256.25 & 908715.40 & 263.73 & 0.42 & 176255.00 & 12259.29 & 3425.00 & 13.97 & 405130.00 & 17.81 & -0.873 \\
\hline Hunan & & & & & & & & & & & & \\
\hline
\end{tabular}

\subsection{The Calculation Process}

Because the dimension and the order of magnitudes of the different variables in table 1 are different, all the indicators are standardized so as to make each variable comparable, and analyze the data in more equal condition. The new data after standardization are shown as table 2 .

Table 2. The data after standardization of factor analysis of agricultural products logistics in Hunan Province

\begin{tabular}{|c|c|c|c|c|c|c|c|c|c|c|c|c|}
\hline $\begin{array}{l}\text { Name of } \\
\text { the city }\end{array}$ & $\begin{array}{l}X_{1} \\
(100,000, \\
000 \text { yuan })\end{array}$ & $\begin{array}{l}X_{2} \\
(10,000 \\
\text { person })\end{array}$ & $\begin{array}{l}X_{3} \\
(10,000 \\
\text { yuan })\end{array}$ & $\begin{array}{l}X_{4} \\
(10,000 \\
\text { ton })\end{array}$ & $\begin{array}{l}X_{5} \\
(10,000 \\
\text { person })\end{array}$ & $\begin{array}{l}\mathrm{X}_{6} \\
\text { (unit) }\end{array}$ & $\begin{array}{l}\mathrm{X}_{7} \\
(\mathrm{~km})\end{array}$ & $\begin{array}{l}X_{8} \\
(10,000 \\
\text { ton })\end{array}$ & $\begin{array}{l}X_{9} \\
(100,000, \\
000 \text { yuan })\end{array}$ & $\begin{array}{l}X_{10} \\
(10,000 \\
\text { yuan })\end{array}$ & $\begin{array}{l}X_{11} \\
(10,000 \\
\text { subscribers })\end{array}$ & $\begin{array}{l}\mathrm{X}_{12} \\
\text { (ton SCE/ } \\
10,000 \text { Yuan }\end{array}$ \\
\hline Changsha & 3.21 & 1.36 & 0.82 & 1.06 & 2.37 & 2.70 & -0.24 & 1.99 & 3.31 & 3.30 & 3.19 & 1.11 \\
\hline Zhuzhou & 0.09 & -0.47 & -0.67 & -0.44 & -0.76 & -0.01 & -0.63 & 0.39 & -0.05 & -0.49 & 0.26 & 0.01 \\
\hline Xiangtan & -0.24 & -1.11 & -0.82 & -0.86 & -0.34 & -0.53 & -1.82 & -0.57 & -0.38 & -0.37 & -0.50 & -1.14 \\
\hline Hengyang & 0.22 & 1.40 & 1.48 & 1.08 & -0.66 & 0.35 & 0.82 & 0.82 & 0.16 & -0.24 & 0.36 & 0.27 \\
\hline Shaoyang & -0.41 & 1.37 & 0.29 & 0.37 & 1.67 & 0.07 & 1.04 & 0.52 & -0.06 & 0.21 & -0.06 & 0.11 \\
\hline Yueyang & 0.35 & 0.44 & 0.76 & 0.71 & 0.85 & -0.40 & 0.72 & 0.65 & 0.06 & -0.53 & 0.20 & -0.14 \\
\hline Changde & 0.28 & 0.58 & 1.44 & 0.99 & -0.66 & 0.89 & 1.15 & -0.25 & 0.14 & -0.12 & 0.22 & 0.81 \\
\hline Zhangjiajie & -0.88 & -1.84 & -1.66 & -1.70 & -0.71 & -1.46 & -1.62 & -1.51 & -0.89 & -0.61 & -0.95 & 0.91 \\
\hline Yiyang & -0.43 & -0.23 & 0.08 & 0.16 & -0.62 & -0.27 & -0.16 & -0.45 & -0.31 & -0.41 & -0.55 & 0.47 \\
\hline Chenzhou & -0.07 & -0.06 & -0.24 & -0.13 & -0.57 & 0.09 & 0.08 & 1.08 & -0.26 & 0.41 & -0.25 & -0.17 \\
\hline Yongzhou & -0.38 & 0.29 & 0.96 & 1.53 & -0.43 & 0.23 & 1.24 & -0.55 & -0.35 & -0.65 & -0.44 & 0.08 \\
\hline Huaihua & -0.46 & 0.02 & -0.49 & -0.48 & 0.74 & -0.17 & 0.70 & -1.20 & -0.31 & -0.41 & -0.33 & 0.28 \\
\hline Loudi & -0.46 & -0.52 & -0.50 & -1.05 & -0.36 & -0.07 & -0.41 & 0.35 & -0.31 & -0.11 & -0.38 & -2.91 \\
\hline West & -0.83 & -1.23 & -1.44 & -1.24 & -0.52 & -1.44 & -0.89 & -1.27 & -0.75 & 0.01 & -0.76 & 0.32 \\
\hline Hunan & & & & & & & & & & & & \\
\hline
\end{tabular}

The KMO value is used to compare the simple correlation and partial correlation coefficient of items, which values from 0 to 1 . When it is greater than 0.9 , the factor analysis is a very suitable method. When it is from 0.6 to 0.9 , the factor analysis is a suitable method. When it is less than 0.6 , the factor analysis is not a suitable method. The result of Bartlett's Test is to examine the significance of correlation coefficient of items. If the Sig is less than 0.05 , the factor analysis can be conducted. 
Table 3. The result of KMO and Bartlett's test

\begin{tabular}{lll}
\hline Kaiser-Meyer-Olkin Measure of Sampling Adequacy. & .672 \\
\hline Bartlett's Test of Sphericity & Approx. Chi-Square & 208.251 \\
& df & 66 \\
& Sig. & .000 \\
\hline
\end{tabular}

As shown in table 3, the test value of KMO is $0.672(>0.6)$, which indicates factor analysis is suitable for this investigation. According to the result of Bartlett's test of sphericity, the value of approx.chi-square is 208.251, and the significance probability is 0.000 , therefore the investigation data can be analyzed by using factor analysis method.

In the process of analyzing factor, the Principal Factor Analysis is utilized. The Varimax is used for factor rotation, and the factors with eigenvalue greater than 1 are extracted. As shown in table 4, there are three factors with eigenvalue greater than 1 . The rate of total variance explained of these three factors is $89.774 \%$, which covers most of the variable information. Therefore, the first three factors are selected as the common factors.

Table 4. Total variance explained

\begin{tabular}{|c|c|c|c|c|c|c|c|c|c|}
\hline \multirow{2}{*}{ Component } & \multicolumn{3}{|c|}{ Initial Eigenvalues } & \multicolumn{3}{|c|}{ Extraction Sums of Squared Loadings } & \multicolumn{3}{|c|}{ Rotation Sums of Squared Loadings } \\
\hline & Total & $\%$ of Variance & Cumulative $\%$ & Total & $\%$ of Variance & Cumulative \% & Total & $\%$ of Variance & Cumulative $\%$ \\
\hline 1 & 7.397 & 61.643 & 61.643 & 7.397 & 61.643 & 61.643 & 5.773 & 48.111 & 48.111 \\
\hline 2 & 2.316 & 19.298 & 80.941 & 2.316 & 19.298 & 80.941 & 3.886 & 32.380 & 80.491 \\
\hline 3 & 1.060 & 8.834 & 89.774 & 1.060 & 8.834 & 89.774 & 1.114 & 9.283 & 89.774 \\
\hline 4 & .629 & 5.245 & 95.019 & & & & & & \\
\hline 5 & .244 & 2.031 & 97.050 & & & & & & \\
\hline 6 & .152 & 1.266 & 98.316 & & & & & & \\
\hline 7 & .074 & .617 & 98.933 & & & & & & \\
\hline 8 & .061 & .512 & 99.445 & & & & & & \\
\hline 9 & .041 & .345 & 99.790 & & & & & & \\
\hline 10 & .021 & .172 & 99.961 & & & & & & \\
\hline 11 & .003 & .024 & 99.985 & & & & & & \\
\hline 12 & .002 & .015 & 100.000 & & & & & & \\
\hline
\end{tabular}

Extraction Method: Principal Component Analysis.

By using Varimax rotation method, the factor loading of each indicator is shown as table 5.

Table 5. Rotated component matrix

\begin{tabular}{|c|c|c|c|}
\hline & \multicolumn{3}{|c|}{ Component } \\
\hline & 1 & 2 & 3 \\
\hline $\mathrm{X}_{1}$ (Regional GDP) & .947 & .212 & .106 \\
\hline $\mathrm{X}_{2}$ (Population) & .469 & .839 & .015 \\
\hline $\begin{array}{l}X_{3} \text { (Gross output value of farming, forestry, animal husbandry and } \\
\text { fishery) }\end{array}$ & .266 & .930 & .025 \\
\hline $\mathrm{X}_{4}$ (Total output of agricultural products) & .299 & .905 & .153 \\
\hline $\mathrm{X}_{5}$ (Employees in traffic, transport, storage and post) & .711 & .172 & .112 \\
\hline $\mathrm{X}_{6}$ (Number of civil vehicles owned) & .813 & .489. & .001 \\
\hline
\end{tabular}




\begin{tabular}{llll}
\hline $\mathrm{X}_{7}$ (Total length of highways) & -.052 & .490 & .085 \\
$\mathrm{X}_{8}$ (Freight traffic) & .741 & .414 & -.346 \\
$\mathrm{X}_{9}$ (Revenue from postal and telecommunication Service) & .965 & .204 & .114 \\
$\mathrm{X}_{10}$ (Investment in transport, storage and post) & .955 & -.016 & .103 \\
$\mathrm{X}_{11}$ (Number of internet users) & .950 & .243 & .106 \\
$\mathrm{X}_{12}$ (Opposite number of energy consumption of unit GDP) & .176 & .161 & .951 \\
\hline
\end{tabular}

Extraction Method: Principal Component Analysis.

The following conclusions can be drawn by analyzing the data of table 5 . The first common factor $\mathrm{F} 1$ has greater loading on the indicators $\mathrm{X} 1, \mathrm{X} 5, \mathrm{X} 6, \mathrm{X} 8, \mathrm{X} 9, \mathrm{X} 10$ andX11. These indicators are connected with the essential element needed to ensure agricultural products logistics activities go smoothly, and can comprehensively reflect the agricultural products logistics development in Hunan Province in the aspect of market supply condition, which can be named as "supply factor" with the contribution rate of $48.111 \%$. The second common factor F2 has greater loading on the indicators X2, X3 and X4. These indicators are connected with the needs of consumers for agricultural products logistics activities and can comprehensively reflect the agricultural products logistics development in Hunan Province in the aspect of market demand condition, which can be named as "demand factor" with the contribution rate of $32.380 \%$. The third common factor reflects the level of energy consumption of agricultural products logistics activities in Hunan Province, which can be named as "energy consumption factor" with contribution rate of $9.283 \%$

According to table 4 and table 5, the score function of each common factor can be obtained as follows:

$\mathrm{F} 1=0.947 \mathrm{X} 1+0.469 \mathrm{X} 2+0.266 \mathrm{X} 3+0.299 \mathrm{X} 4+0.711 \mathrm{X} 5+0.813 \mathrm{X} 6-0.052 \mathrm{X} 7+0.741 \mathrm{X} 8+0.965 \mathrm{X} 9+0.955 \mathrm{X} 10+0.950 \mathrm{X}$ $11+0.176 \times 12$

$\mathrm{F} 2=0.212 \mathrm{X} 1+0.839 \mathrm{X} 2+0.930 \mathrm{X} 3+0.905 \mathrm{X} 4+0.172 \mathrm{X} 5+0.489 \mathrm{X} 6+0.940 \mathrm{X} 7+0.414 \mathrm{X} 8+0.201 \mathrm{X} 9-0.016 \mathrm{X} 10+0.243 \mathrm{X}$ $11+0.161 \times 12$

$\mathrm{F} 3=0.106 \mathrm{X} 1+0.015 \mathrm{X} 2+0.025 \mathrm{X} 3+0.153 \mathrm{X} 4+0.112 \mathrm{X} 5+0.001 \mathrm{X} 6+0.085 \mathrm{X} 7-0.346 \mathrm{X} 8+0.114 \mathrm{X} 9+0.103 \mathrm{X} 10+0.106 \mathrm{X}$ $11+0.951 \times 12$

And the factor evaluation model of agricultural products logistics in Hunan Province can consequently be obtained:

$\mathrm{F}=\left(48.111 \times \mathrm{F}_{1}+32.380 \times \mathrm{F}_{2}+9.283 \times \mathrm{F}_{3}\right) / 89.774$

Taking the data into the model, the comprehensive evaluation score of the development of agricultural products logistics in 14 cities of Hunan Province can be obtained. Sorted by the value of F1, F2, F3 and F from high to low, the scores of 14 cities are shown as table 6 .

Table 6. The comprehensive score and rank of agricultural products logistics in Hunan

\begin{tabular}{|c|c|c|c|c|c|c|c|}
\hline & $\mathrm{F}_{1}$ & & $\mathrm{~F}_{2}$ & & $\mathrm{~F}_{3}$ & & $\mathrm{~F}$ \\
\hline Changsha & 3.32 & Hengyang & 1.37 & Zhangjiajie & 1.28 & Changsha & 1.80 \\
\hline Chenzhou & 0.07 & Yongzhou & 1.29 & Changde & 0.75 & Hengyang & 0.4 \\
\hline Zhuzhou & 0.06 & Changde & 1.2 & West Hunan & 0.74 & Changde & 0.37 \\
\hline Shaoyang & 0.05 & Shaoyang & 0.79 & Huaihua & 0.7 & Shaoyang & 0.31 \\
\hline Loudi & 0 & Yueyang & 0.76 & Changsha & 0.67 & Yueyang & 0.22 \\
\hline Yueyang & -0.04 & Yiyang & 0.07 & Yiyang & 0.51 & Yongzhou & 0.06 \\
\hline Xiangtan & -0.07 & Chenzhou & -0.01 & Yongzhou & 0.27 & Chenzhou & -0.03 \\
\hline Hengyang & -0.15 & Huaihua & -0.03 & Shaoyang & -0.05 & Zhuzhou & -0.17 \\
\hline Changde & -0.26 & Changsha & -0.14 & Hengyang & -0.15 & Huaihua & -0.17 \\
\hline Huaihua & -0.43 & Loudi & -0.5 & Zhuzhou & -0.2 & Yiyang & -0.2 \\
\hline Yiyang & -0.51 & Zhuzhou & -0.51 & Yueyang & -0.27 & Loudi & -0.47 \\
\hline West Hunan & -0.56 & Xiangtan & -1.21 & Chenzhou & -0.6 & Xiangtan & -0.56 \\
\hline Zhangjiajie & -0.69 & West Hunan & -1.3 & Xiangtan & -0.85 & West Hunan & -0.69 \\
\hline Yongzhou & -0.8 & Zhangjiajie & -1.77 & Loudi & -2.79 & Zhangjiajie & -0.88 \\
\hline
\end{tabular}


According to table 6, Changsha, Chenzhou, Zhuzhou and Shaoyang are at the top of the list and West Hunan, Zhangjiajie and Yongzhou are at the bottom of the list in terms of the supply ability of agricultural products logistics. Hengyang, Yongzhou and Changde rank top 3 in terms of the agricultural products logistics demand. The ranking of Xiangtan, West Hunan and Zhangjiajie are the last three in this aspect. Zhangjiajie, Changde and West Hunan do better job than other cities for energy consumption in agricultural products logistics activities. But Loudi has the worst performance in this aspect. The top 3 cities with comprehensive strength of the agricultural products logistics are Changsha, Hengyang and Changde. Xiangtan, West Hunan and Zhangjiajie rank the last three.

\subsection{The Cluster Analysis}

Based on the data of principal component indicators obtained by factor analysis, the sample matrix of cluster analysis is established. The hierarchical clustering method is used to do the cluster analysis on agricultural products logistics system of Hunan Province. The results of analysis are shown as figure 1.
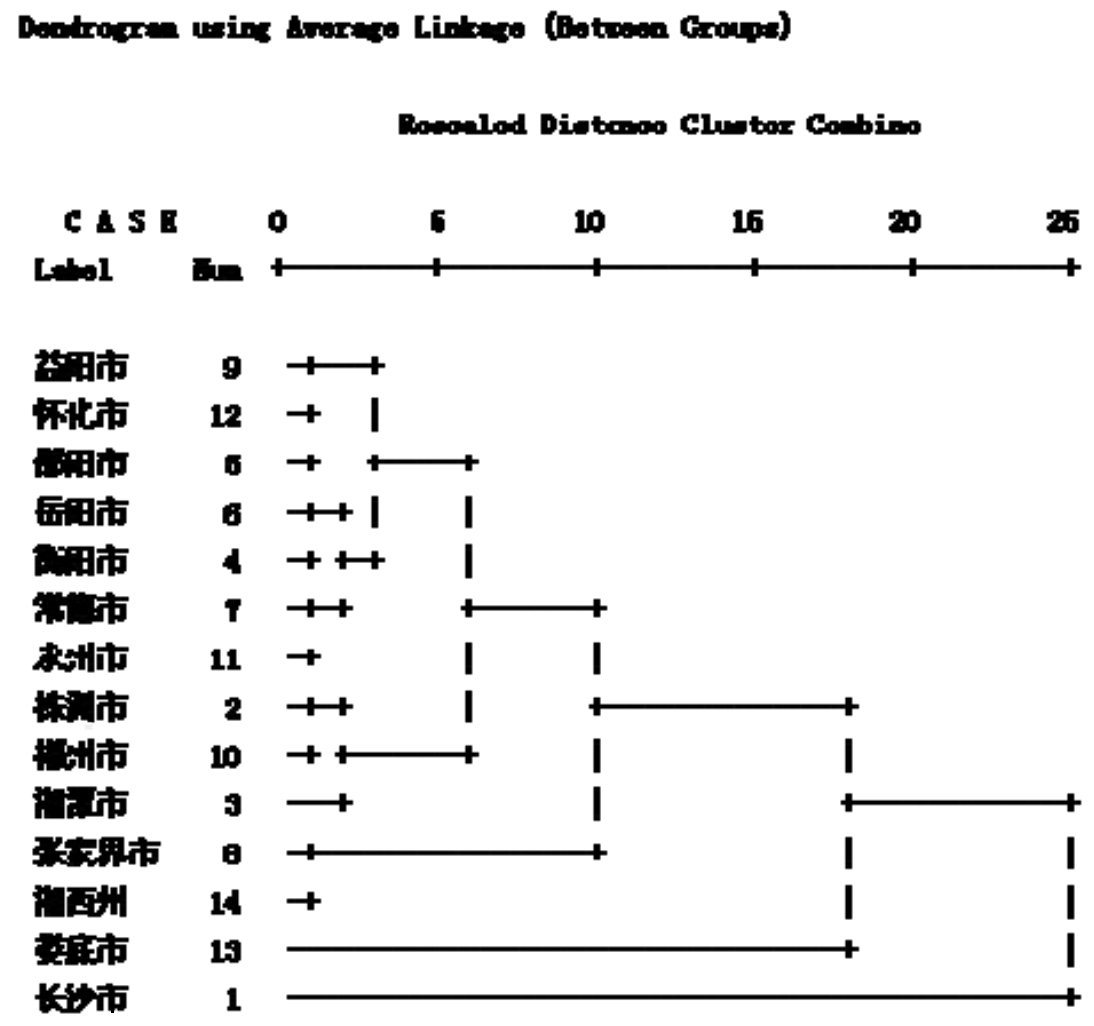

Figure 1. The dendrogram of agricultural products logistics of Hunan Province

Based on figure 1 and table 6, the 14 cities of Hunan Province can be classified as five categories according to the comprehensive capability of agricultural products logistics. The first category, Changsha, has the strongest comprehensive capability of agricultural products logistics, especially the supply ability, and enjoys the relative low energy consumption of agricultural products logistics. The second category, Yiyang, Huaihua, Shaoyang, Yueyang, Hengyang, Changde and Yongzhou, have relatively good capability of agricultural products logistics, and have large demand of agricultural products logistics due to the abundant resource of agricultural products output. The third category, Zhuzhou and Chenzhou, have the medium level comprehensive capability of agricultural products logistics and relatively good performance in supply ability. But the energy consumption of agricultural products logistics activities of these cities is high. The fourth category, Xiangtan, Zhangjiajie and West Hunan, have the weakest comprehensive capability of agricultural products logistics, both in supply and demand. The energy consumption of agricultural products logistics activities in these cities is at a relative low level. The fifth category, Loudi, has the weak comprehensive capability of agricultural products logistics, and the poorest performance of energy consumption of agricultural products logistics activities. 


\section{Conclusions and Recommendations}

The increasing living standard of consumer generates greater demand of agricultural products. Given this background, the green development of agricultural products in Hunan Province means improving the capability of providing the agricultural products logistics service from the aspects of processing, transport, storage and distribution, guaranteeing the quality and safety of agricultural products in the processing of logistics, increasing the efficiency of agricultural products logistics activities and reducing the level of energy consumption of agricultural products logistics to the greatest extent.

Based on the remarkable advantages of comprehensive capability of the whole province, the first category city has the condition to develop advanced logistics mode. According to its current characteristics of the economy, the development of transport and storage industry, information service industry should be given special attention so as to provide strong support to the development of agricultural products logistics system of the whole province. To take the agricultural products logistics mode lead by the chain supermarket, the third party logistics as the main development pattern. To take the agricultural products logistics mode lead by production and processing enterprises, wholesale market as the second development pattern. The third party cold chain logistics needs to be enhanced by improving the research and promotion of cold chain logistics technology, increasing the number of refrigeration car and refrigeration storage, establishing frozen products processing and distribution center, and boosting the intensive distribution and joint distribution. Moreover, the control standard of temperature and moisture of agricultural products in the process of transport, storage, processing, and distribution also needs to be established so as to decrease the loss and waste of agricultural products.

For the second category cities, the reasonable planning of agriculture logistics base is vital. The reconstruction and expansion a batch of large-medium sized professional agricultural products wholesale markets with strong distribution function and wide radiation scope in the main producing area of agricultural products are needed. To speed up the construction of information management system of agricultural products logistics and form the integrated information network of agricultural products market. The application of barcode technology in the whole process of agricultural products logistics, the promotion of online transaction of agricultural products can significantly increase the efficiency of agricultural products logistics. The continuous contact and good communication among agricultural products logistics enterprises can assure the smooth connection of the demand and supply of agricultural products. The government can provide the assistance to help those outstanding logistics enterprises to explore the market of rural areas and become the backbone of agricultural products logistics system. The government also can encourage the enterprises dealing in the transport, storage and freight forwarding service to expand the scope of their business and become the suppliers of agricultural products logistics service.

For the third category cities, the facilities construction of processing, storage and transport of agricultural products is necessary, especially the research and development of temperature control equipment and damp proof device of grain depot, cotton depot and refrigeration warehouse. To reduce the number of circulation checkpoints and achieve the reasonable connection of various transportation means. To adopt the logistics plan with little negative impact on the environment in planning the logistics system and decision making of logistics activities. The trunk with small discharge capacity, short distance distribution, and night delivery are highly recommended.

For the fourth category cities, the construction of logistics infrastructure needs to be greatly reinforced. The improvement of the accessibility of highway, the road grade can greatly assure the smooth delivery of agricultural products. To cultivate and establish professional marketing organization of agricultural products, and increase the consumer demand for agricultural products, thus increasing the demand for agricultural products logistics.

For the fifth category cities, the first task is to decrease the negative impact on environment during the process of transport, storage, carrying, packing, and processing agricultural products. The energy consumption, pollutant discharge, and noise making of means of conveyance need to be strictly controlled. The realization of energy conservation and emissions reduction partially depends on the reasonable layout and planning of freight network and distribution center, the route shortening and reduction of empty loading rate.

\section{References}

HAN, S. (2009). Research on the construction of green logistics and supply chain system of agricultural commodities in Henan Province. China Business and Trade, 8, 21-24.

HUANG, F. H., \& ZHOU, M. (2008). Analysis of the agricultural products logistics development in Hunan 
Province from the perspective of joint logistics. Issues in Agricultural Economy, 8, 90-93.

HUANG, F. H., \& ZHOU, M. (2008). Analysis of the agricultural products logistics development in Hunan Province from the perspective of joint logistics. Issues in Agricultural Economy, 8, 90-93.

LI, C. X. (2009). Promoting the green logistics of agricultural products based on the construction of new rural. Jiangshu Commercial Forum, 8, 59-61.

LI, C. X. (2009). The promotion strategy of green logistics of agricultural products. Hubei Social Science, 5, 94-97.

LI, M. (2011). Analysis on the current situation of agricultural products logistics in Hunan Province. Jiangshu Commercial Forum, 2, 75-76.

LI, W. Q. (2010). The promotion strategy of green logistics of agricultural products in Guangxi Province based on the ASEAN free trade area. Jiangshu Commercial Forum, 8, 87-89.

LIU, C. J. (2011). Analysis on the security mechanism of the agricultural products logistics development in Hunan Province. China Business \& Trade, 10, 150-151.

LU, L. Y. (2007). Discussion on the problems of green logistics of agricultural products in China. Anhui Agricultural Sciences, 3, 853-854.

LU, N. (2012). Discussion on the development situation of green logistics of agricultural products in China. Journal of Inner Mongolia agricultural university (social science edition), 3, 72-74.

NIU, X. J. (2010). Discussion on the problem and countermeasures of the development of green logistics of agricultural products in China. Logistics Technology, 7, 32-33, 43.

PANG, Y., \& WANG, Z. W. (2008). The research of the modern logistics system of agricultural products in Hunan Province. China Logistics and Purchasing, 4, 74-75.

SHENG, Y. (2009). The construction of modern logistics system of agricultural products in Hunan Province. Technological Development of Enterprise, 4, 118-120.

WANG, W. W. (2010). The existing problem and countermeasures of green logistics of agricultural products in China. Practice in Foreign Economic Relations and Trade, 10, 85-88.

WANG, W., \& LIU, X. T. (2010). Thoughts on improving the green logistics system of agricultural products in Heilongjiang Province. Logistics Technology, 12, 8-10.

WU, X. Y. (2008). Factor model analysis on the port logistics of both sides of Taiwan straits. Fujian Normal University.

XU, H. L. (2011). Development and experience learning of the developed countries agricultural products green logistics. Journal of Central University of Finance \& Economics, 12, 70-74.

XU, H. L. (2012). The discussion summary of the foreign agricultural products green logistics development. China Business and Market, 1, 28-32.

YANG, L., \& ZHANG, Y. Z. (2010). The construction of agricultural products logistics financial risk management system based on factor analysis. Guangdong Agricultural Sciences, 4, 251-253.

ZOU, X. M., \& LI, Q. L. (2010). Research on agricultural products logistics of Hunan Province. Journal of Yangtze University (natural science edition), 12, 78-81.

\section{Copyrights}

Copyright for this article is retained by the author(s), with first publication rights granted to the journal.

This is an open-access article distributed under the terms and conditions of the Creative Commons Attribution license (http://creativecommons.org/licenses/by/3.0/). 